\title{
Geodynamics Relationship of Sabak Back Arc Volcanic and Geragai Geothermal Features, Tanjabtim, Jambi, Indonesia
}

\author{
Hari Wiki Utama ${ }^{1, *}$ Yulia Morsa Said ${ }^{2}$, D.M. Magdalena Ritonga ${ }^{3}$, Eko \\ Kurniantoro $^{4}$ \\ ${ }^{1234}$ Department of Geological Engineering, Faculty of Science and Technology, Jambi University, Indonesia \\ "Corresponding author.Email: $\underline{\text { h.wikiutama@unja.ac.id }}$
}

\begin{abstract}
Jambi Sub-basin is a sedimentary back-arc basin in Sumatra with the numerous geodynamic processes of the extensional basin. It is a prospect and producer of hydrocarbon Sumatra, Indonesia, and it's part of the South Sumatra Basin. The presence of trachy basaltic lava on the Sabak (Jambi Sub-basin), Tanjabtim, guides back-arc volcanism. Geragai geothermal features are the Northwestern part of Sabak back-arc volcanic as a hint of the connection between both of them. The geological investigation of geodynamics is essential for understanding the possibility between Sabak Back Arc Volcanic and Geragai Geothermal Features. Geological methods research consists of geological outcrop data such as lithology characteristics, the structural geology element, the physical part of geothermal manifestation, and mineral composition analyzed. Geological evidence of the Sabak Back Arc Volcanic compile of trachy basaltic lava is scoria, vesicular, amygdaloidal, and rophy structure. These are perpendicular that magma eruption, which extrusive processes. A geological survey to show Geragai geothermal features is composed of hot springs with temperatures about $50^{\circ} \mathrm{C}$ $55^{\circ} \mathrm{C}, \mathrm{pH} 6.2-6.8$, the appearance of Claystone Kasai Formation, and swamp sediment. Bicarbonate fluid indicates a strong influence of meteoric water and mixing processes of the interaction fluid geothermal with wall rock and thickness of water table. The existence of dextral fault with Northwestern - Southeastern orientation of Sabak Back Arc Volcanic the continued to Geragai geothermal hot spring manifestation, were buried under Alluvium. The dextral mark directly continues to appearance geothermal features manifestation. It assures there is a facility of the pathway the geothermal features on the surface manifestation. The geothermal system on Geragai has a spatial connection to back-arc volcanism on Sabak. The convinced heat transfer dormant volcanic of Sabak Back Arc Volcanic to Geragai geothermal features passes through dextral fault system.
\end{abstract}

Keywords: Dextral Fault, Geragai Geothermal Features, Sabak Back Arc Volcanic.

\section{INTRODUCTION}

Sumatra's sedimentary back-arc basin is extensional the prospect and producer of hydrocarbon in Indonesia, such as the South Sumatra Basin, especially the Jambi Sub-basin [1]. The presence of trachy basaltic lava on the Parit Culum Sabak, the part of the Jambi Sub-basin, indicates the active fossil volcano. This research is a new study about outcrop lava identification, particularly Sabak Back Arc Volcanic (SBAV). It is a Quartenary Pleistocene product [2]. The appearance of geothermal features manifestation such ac hot spring and hot pool in
Geragai the Northwestern of SBAV identifies the relationship between them.

Monitoring of digital elevation model the aid of Digital Elevation Model National of Indonesia Geospatial Agency (DEMNAS), which have resolution 8 $\mathrm{m}$, processing digital elevation model by ArcGIS software geoscience. Was more detailed interpretation could achieve distribution of trachy basaltic lava on SBAV and structural delineation. This research aims to know the existence of SBAV, which the evidence of outcrop lava with a porous structure, understand the appearance of geothermal features manifestation in Geragai, and afterward to detect the geodynamics 
relationship both of them which connects is structural geology of dextral fault. Geodynamics aspect the understanding geological setting between two connect geological area based on rock type, structural geology, landscape, and tectonic.

\section{REGIONAL GEOLOGY}

Sumatra locates island in the western part of Indonesia Archipelago, which has experienced geological processes such as collision, transcurrent system, obduction during Carbon-Permian to Cretaceous and subduction processes Tertiary to Quarternary, and their intensive magmatism, volcanism, structural, the associated with conducting the Present-day of structural and stratigraphy [3]. These processes produce a complex geological setting in the Sumatra can simply divide into 1) back high of Barisan Range in central Sumatra, which is orientation North-Northwest - South-Southeast, 2) Sumatra Fault System the associated to Barisan Range the initial forming and connects to the pull-apart basin, active volcanism, and geothermal manifestation, 3) Tigapuluh Hill is a high basement Carbon-Permian the boundary of South Sumatra Basin to Central Sumatra Basin. The similarly Tigapuluh Hill is Asahan Arc, which morphology high the boundary of Central Sumatra Basin to North Sumatra Basin, 4) Low Hills and Wavy Plain the geological area back-arc basin in Sumatra such as South
Sumatra Basin, Central Sumatra Basin, and North Sumatra Basin, 5) Outer Arc is composed of Enggano, Mentawai, Nias, and their part of forearc basin the associated to Mentawai Fault and Mentawai-Siobolga Basin between of forearc basin and Barisan Range the western edge of Sumatra, 6) Sunda Shelf is a shelf the eastern part of the back-arc basin the related to BentongRaub Suture Zone (Figure 1).

The Sumatra basement terrane complex consists of Sibumasu terrane, West Sumatra terrane, and Woyla Arc terrane [4]. Collision Sibumasu to East Malaya during Permian the formed of the high of Bentong-Raub Suture Zone. Truscurrenst system of West Sumatra to Sibumasu obtained Medial Tectonic Sumatra Zone on TriassicJurassic, and Cretaceous the obduction Woyla Arc to West Sumatra the formed of Woyla Nappe Suture. These complex processes consist of basement stratigraphy and structural in Sumatra [5]. During Tertiary to Early Quarternary, numerous geological processes including Paleogene magmatism, volcanism, and continued stratigraphy, Neogene activation of Sumatra Fault System the continued magmatism, volcanism, and stratigraphy and their response to rotating counterclockwise of Sumatra, and Holocene to Presentday interchanging of structural geology and continued stratigraphy.

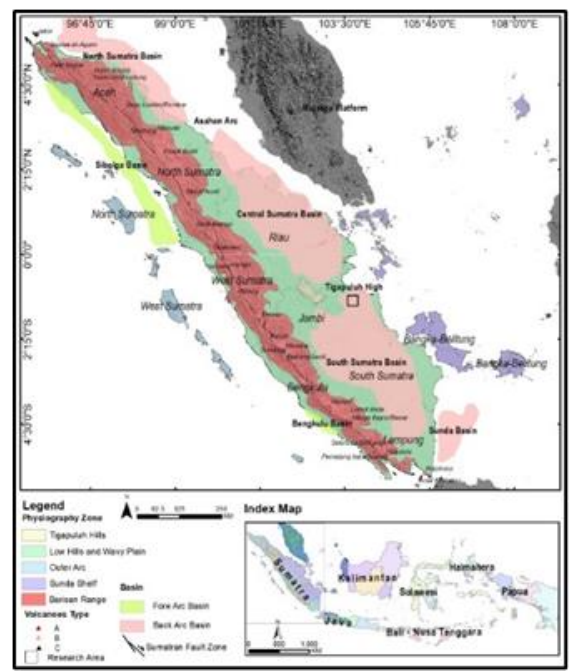

Figure 1. Geological settings in Sumatra consist of physiography, tectonic zone, and the association of sedimentary basin [1] [8] [6]. The black box is a research area on Sabak and Geragai, Tanjabtim, Jambi.

Sumatra's complex geological processes evidence of back-arc volcanism on Sabak and geothermal features manifestation on Garage. The thesis is connected to interpret dextral fault, which Northwestern Southeastern based on the geological map [2] and detailed interpretation DEMNAS. The existence of Quarternary and geothermal features manifestation on Barisan Range [6]. Back arc volcanism on Sabak and geothermal features declaration on Geragai are geological anomaly processes in Sumatra.

\section{SAMPLE AND METHODOLOGY}

This research started data compilation the geological map of Jambi sheet with a scale of 1:100.000 and digital elevation model. Geological maps were managed datasets to know the presence of igneous rock on a 
geological map the term of andesitic lava, but not research published the explain that it is part of volcanic fossil "lava." The support data which the Digital Elevation Model Nation of Indonesia Geospatial Agency (DEMNAS) with high resolution eight $\mathrm{m}$. These overlapping data for to comprehend igneous rock areas emphasize the pattern of model elevation digital. Its form of extrusive product patterns on volcanic systems. Delineation of structural geology such as fault on igneous rock and surrounding and anticline on the sedimentary product. The mark connects to the appearance of geothermal features on Geragai, the Northwestern part of lava on Sabak with under buried fault Alluvium Quarternary between lava on Sabak and Geragai geothermal features.

Geological collecting data the fieldwork activity using observation outcrop including rock type, texture, and structure of the rock, mineralogy composition, and the proof of structural geology that orientation fault plane based on compilation data to detailed DEMNAS interpretation and geological outcrop. The geothermal features manifestation the observe manifestation such as hot spring and hot pool with complexity the measured physical characteristic. It compiles temperature, $\mathrm{pH}$, water clarity, Total Dissolved Solid (TDS), Electrical Conductivity (DHL), and understanding of sinter deposit surrounding geothermal manifestation. Comprehend fault type, orientation, fault continued identification as descriptive, kinematics, and the fault system dynamics. It obtained the hint for understanding the geodynamics relationship between Sabak Back Arc Volcanic and Geragai Geothermal Features.

Petrographic study conduct to represent rock type by examining thin section optical mineralogy to determine the rock type, structure and texture, and mineral composition. Identification of oriented and aligned texture the study analysis for understanding igneous petrogenetic of extrusive processes,

\section{RESULTS AND DISCUSSION RESULTS}

\subsection{Fossil Volcanic Back Arc}

Basaltic lava outcrop in the field still fresh rock. It has vesicular-scoria characteristics are the porous structure, amygdaloidal where the porous fill of secondary minerals such as calcite, and rophy structure. The volcanic landscape is relatively flat with about 25 $\mathrm{km} 2$ in diameter combine with DEMNAS data analysis. The existence of lava grows wider inter fingering from basaltic lava of Northnorthwestern - Southsoutheastern. Fault plane structure to show on basaltic lava outcrop which is 1) $\mathrm{N} 330^{\circ} \mathrm{E} / 80^{\circ}$ (fault plane) and rake $6^{\circ}$ strikeslip which SSE-NNW, 2) $\mathrm{N} 070^{\circ} \mathrm{E} / 78^{\circ}$ (fault plane) and rake $7^{\circ}$ strike-slip which ENE-WSW. Analysis outcrop in the field and studio of fault element obtained of strikeslip which dextral fault and sinistral fault (Figure 2).

In the field, do not find distinct contact stratigraphy to the sedimentary product of Mio-Pliocene Muaraenim Formation, cause flat topography with the intensity of weathering, associated with a swamp area, and some covered by resident and building. Interchanging stratigraphy, the show moves forward a little surrounding of basaltic lava such as interbedded Tuffaceous Sandstone to Tuffaceous Claystone Muaraenim Formation and Plio-Pleistocene Claystone Kasai. Their indicated unconformity stratigraphy contact.

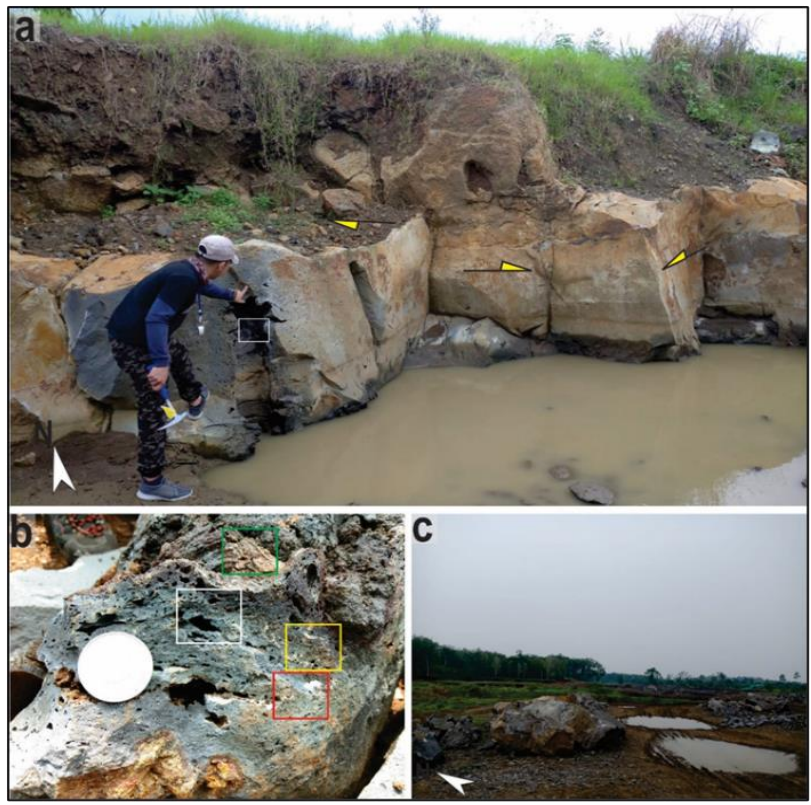

Figure 2. Outcrop of basaltic lava. a) basaltic lava with fault plane orientation, which is dextral fault SSE-NNW and sinistral fault ENE-WSW, b) oriented structure is composed of scoria white box, vesicular yellow box, amygdaloidal red box, and rophy green box, c) basaltic lava volcanic landscape 


\subsection{Geothermal Features}

Geothermal features on Pandan Village, Geragai with elevation $8 \mathrm{~m}$, sedimentary structural landscape the appearance of Claystone Kasai and covered thin layering of clay swamp. It is a hot spring into the hot pool with a pool diameter of about $3 \mathrm{~m} \mathrm{x} 2.5 \mathrm{~m}$ to $2 \mathrm{mx}$ $2 \mathrm{~m}$ and has a 11/s rate of flow.
In the surrounding are not features of hydrothermal alteration rock like generally the associated of other geothermal manifestation. It has characteristics of natural processes (Table 1). The appearance of geothermal features Northnortheastern-Southsouthwestern manifestation have orientation and (Figure 3)

Table 1. Geothermal physical characteristic on Garage

\begin{tabular}{|c|c|c|c|c|c|c|c|c|c|}
\hline \multirow[b]{2}{*}{ No } & \multirow[b]{2}{*}{ Location } & \multirow[b]{2}{*}{ Time } & \multirow[b]{2}{*}{ Lithology } & \multicolumn{2}{|c|}{ Coordinate } & \multirow{2}{*}{$\begin{array}{l}\text { Water } \\
\text { T(C) }\end{array}$} & \multirow{2}{*}{$\begin{array}{l}\text { Air } \\
\text { T(oC }\end{array}$} & \multirow[b]{2}{*}{ pH } & \multirow{2}{*}{$\begin{array}{l}\text { TDS }(\mathrm{ppm}) \text { and } \\
\text { DHL }(\mu \mathrm{m} / \mathrm{cm})\end{array}$} \\
\hline & & & & $\mathbf{m E}$ & $\mathrm{mS}$ & & & & \\
\hline 1. & Gr-1 & $\begin{array}{c}2020 \\
\text { September } \\
20\end{array}$ & $\begin{array}{c}\text { Claystone } \\
\text { and swamp } \\
\text { deposit }\end{array}$ & 352732 & 9872850 & $\begin{array}{l}55.0 \\
53.2 \\
53.0\end{array}$ & $\begin{array}{l}29.2 \\
29.0 \\
29.1\end{array}$ & $\begin{array}{l}6.3 \\
6.5 \\
6.2\end{array}$ & $\begin{array}{r}134 \text { and } 262 \\
134 \text { and } 264 \\
132 \text { and } 260\end{array}$ \\
\hline 2. & Gr-2 & $\begin{array}{c}2020 \\
\text { September } \\
20 \\
\end{array}$ & $\begin{array}{c}\text { Claystone } \\
\text { and swamp } \\
\text { deposit } \\
\end{array}$ & 352734 & 9872850 & $\begin{array}{r}53.1 \\
52.0 \\
51.0 \\
\end{array}$ & $\begin{array}{c}29.5 \\
29.4 \\
29.2 \\
\end{array}$ & $\begin{array}{l}6.4 \\
6.2 \\
\quad 6.3 \\
\end{array}$ & $\begin{array}{c}152 \text { and } 304 \\
150 \text { and } 300 \\
154 \text { and } 307 \\
\end{array}$ \\
\hline 3. & Gr-3 & $\begin{array}{c}2020 \\
\text { September } \\
20\end{array}$ & $\begin{array}{c}\text { Claystone } \\
\text { and swamp } \\
\text { deposit }\end{array}$ & 352786 & 9872881 & $\begin{array}{l}51.0 \\
51.5 \\
50.0\end{array}$ & $\begin{array}{l}29.7 \\
29.6 \\
29.5\end{array}$ & $\begin{array}{l}6.8 \\
6.6 \\
6.7\end{array}$ & $\begin{array}{l}200 \text { and } 400 \\
200 \text { and } 400 \\
198 \text { and } 398\end{array}$ \\
\hline
\end{tabular}

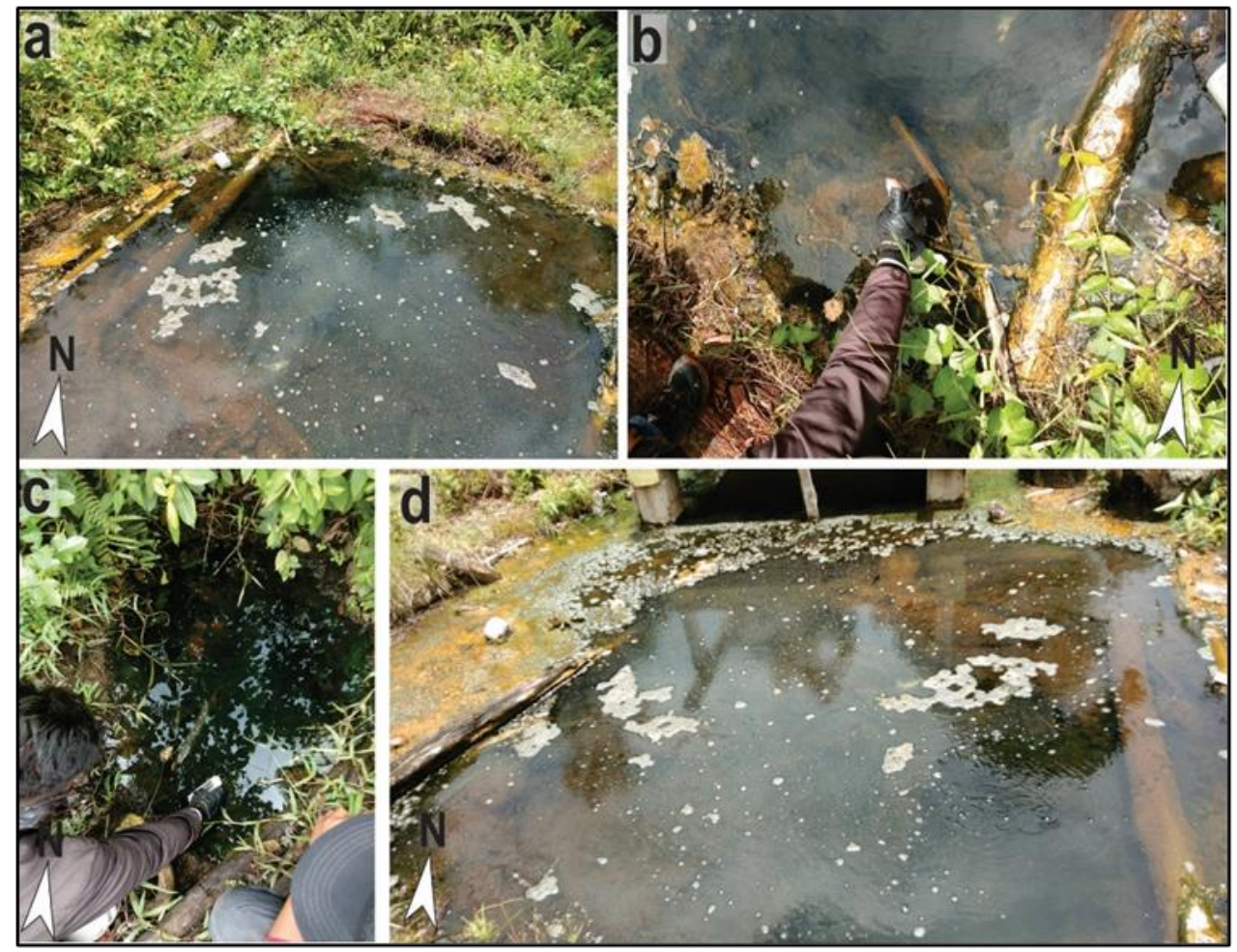

Figure 3. The appearance of geothermal features manifestation on Garage. a-b) Hot spring Gr-1 with medium clarity water, bubble, not sinter deposit, c) Hot spring Gr-2 not sinter deposit, d) Hot spring Gr-3 similarly characteristic of Gr-1, but smaller diameter. The third hot spring location forms the appearance of NorthnortheaternSouthsouthwestern.

\subsection{Petromineralogy}

The petrography analysis method of four samples basaltic lava of Quartenary Volcanic product is composed of alkali feldspar, plagioclase, clinopyroxene, 
olivine, opaque minerals, and groundmass volcanic. The oriented texture of four samples is trachytic, were oriented, and alignment of alkali feldspar, plagioclase.
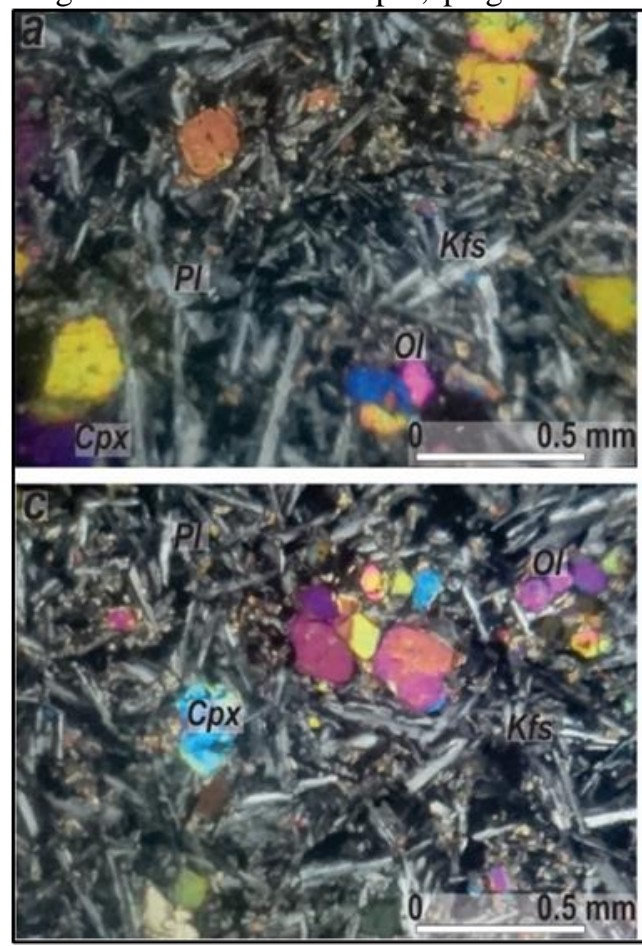

The presence of olivine as an inclusion to clinopyroxene and feldspar (Figure 4).

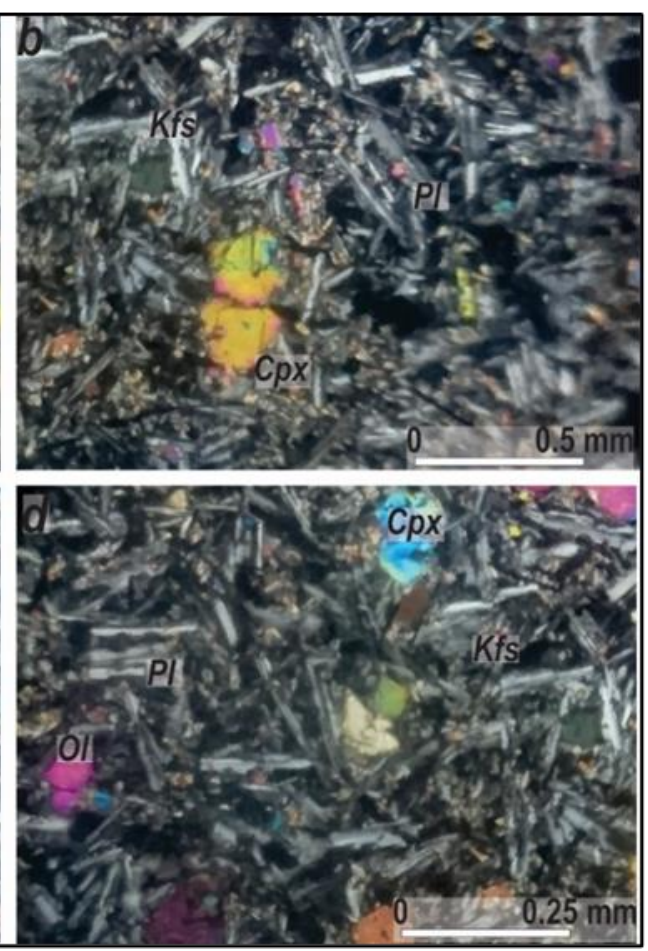

Figure 4. Photomicrography of basaltic lava. a-d) It is composed of alkali feldspar (Kfs), plagioclase (Pl), clinopyroxene $(\mathrm{Cpx})$, olivine $(\mathrm{Ol})$, and volcanic groundmass

\section{DISCUSSION}

\subsection{Sabak Back Arc Volcanic}

It is a product of eruption volcanism processes of extrusive type in the field data to show porous outcrop structure such as vesicular, scoria, amygdaloidal. The rophy design is evidence to strengthen that magma extrusive realize on the surface which is low viscosity. It is the meaning of directly primary magma not experienced differentiation.

The petrographic analysis contains alkali feldspar and plagioclase (feldspar), clinopyroxene, olivine, and groundmass. The primary texture is trachytic, where alkali feldspar and plagioclase oriented alignment indicate flow magma extrusive eruption, so that basaltic to specify trachy basaltic. Combine fieldwork and analysis are evidence of back-arc volcanism.

Jambi Sub-basin is part of the South Sumatra Back Arc Basin. The present Sabak Volcanism Back Arc related to extensional processes of extensional basin continued the Quarternary. The extensional could be triggering continental spreading the initiation graben formed. These processes involve push of primary magma rising and extensional spreading the Northnorthwestern Southsoutheastern which evidence of existence grow wider basaltic lava of Northnorthwestern Southsoutheastern. Still, intens spread SouthwesternWestern (Figure 5) widely.

Rock type of basaltic lava comprises trachy basaltic lava and the convinced alkaline (alkali feldspar) magma series similarly gabro alkali clan. This series of magma related to geodynamic tectonic processes of convergence, oceanic intraplate, and continental intraplate. The consider of geodynamics setting related to back-arc basin continental, that assured consequence processes back-arc basin continued of continental spreading the graben formed, elect to continental spreading intraplate.

\subsection{Garage Geothermal Features}

The appearance of geothermal features is meteoric/peripheral water type which ratio carbonate higher than silica and sulfate, immature water, high boron concentration report to Indonesia Ministry of Energy and Mineral Resources [7] . The assessment of geothermal manifestation origin of heat source shallow reservoir, but geothermal fluid mixing when rising on surface, a side effect of sedimentary rock is proof of high boron concentration. That is equal to the appearance surface manifestation on Claystone Kasai Formation. Assured also the thickness of sedimentary side effect of swamp deposits upper Claystone Kasai Formation. 
Contamination sediment and water table the trigger fluid geothermal meteoric water type.

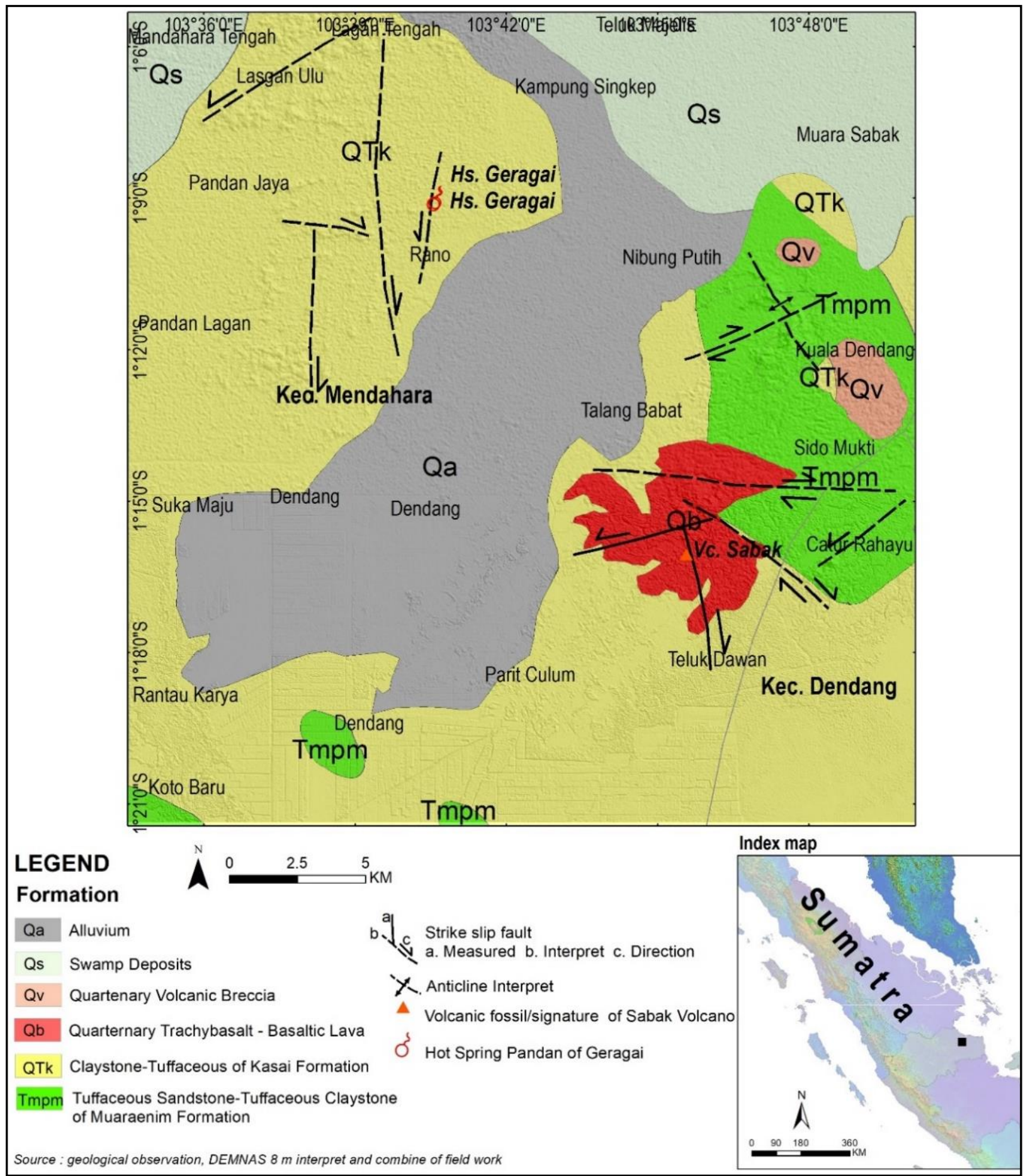

Figure 5. Geological map of Sabak backarc Volcanic and Geragai Geothermal Features

\subsection{The hint of Geodynamic Relationship}

Dextral fault on Sabak Back Arc Volcanic control of volcanic landscape Present-day. Besides, a sinistral defect is associated with anticline on Muaraenim Formation and similarly fault orientation as produce enechelon of regional dextral fault and anticline. Garage geothermal features manifestation the appearance to Northnorteastern - Southsouthwetern and it indicate of structural delineation controlled of sinistral strike-slip.

Dextral fault trachy basaltic lava with dominant composition alkali feldspar and basa plagioclase on Sabak Back Arc Volcanic, sinistral mark on Geragai Geothermal Features, bicarbonate fluid type geothermal. 
There is a hint geodynamic relationship between both of them. The appearance of geothermal fluid on Geragai that assured of Sabak Back Arc Volcanic external heat source, the medium temperature is relevant; bicarbonate fluid type is Ca-rich the related to trachy basaltic lava is Carich, dextral fault on Sabak Back Arc Volcanic as connecting to Geragai Geothermal features through sinistral. Dextral fault and sinistral fault as a shear fault. Shear fault both of them under buried on Quaternary Alluvium and the role of channel way geothermal system. Claystone Kasai Formation as caps rock on Geragai geothermal system.

\section{CONCLUSION}

The existence of trachy basaltic lava, which characteristics of vesicular, scoria, amygdaloidal, and rophy structure, evidence the fossil volcanism active on the back-arc basin. Trachy basaltic lava contains alkali feldspar, basa plagioclase, clinopyroxene, olivine, and groundmass indicate primary origin magma and not differentiation. It is related to continental spreading continued the formation of graben back-arc basin.

Geothermal feature on Geragai with meteoric bicarbonate type, the origin to shallow reservoir geothermal heat source. The side effect of sedimentary formation is very clearly of high Boron content. Geothermal fluid mixing to wall rock, that chloride fluid is complicated found the related to more extended outflow zone.

Dextral fault on Sabak Back Arc Volcanic and Geragai Geothermam Features manifestation assure connection to the geodynamics setting such as shear fault system, volcanic landscape, a tectonic regime of continental intraplate spreading.

Fossil igneous rock of trachy basaltic lava is early to research the behave Sabak Back Arc Volcanic based on an outcrop and petrographic analysis, which requires further research and support geochemical analysis

\section{ACKNOWLEDGMENTS}

Thank you for the PNPB Faculty of Science and Technology UNJA Research Grant 2020 is highly acknowledged for a permit and financial support to conduct this research. This research is part of the support Geology Mengkarang Research Group (GMRP). We are grateful to local people Sabak and Geragai, Tanjabtim, and Jambi for their kind support during the research, especially to the Geological Engineering Program Study, FST, and UNJA.

\section{REFERENCES}

[1] G. Ginger, and K. Fielding, 2005. The Petroleum System and Future Potential of the South Sumatra Basin. Proceedings, Indonesian Petroleum
Association Thirtieth Annual Convention \& Exhibition, IPA05-G-039. Pp. 67-89

[2] S.A. Mangga, S. Santosa, B. Hermanto, 1993. Geological Map of Jambi Quadrangle, Sumatra, Scale 1:250.000. Report Geological Research and Development Centre, Bandung in Press.

[3] E.L. Advocaat, M.L.M. Bonger, A. Rudyawan, M.K. BouDagher-Fadhel, C.G. Langereis, D.J.J. van Hinsbergen, 2018. Early Cretaceous origin of the Woyla Arc (Sumatra, Indonesia) on the Australian plate. Earth and Planetary Science Letters. 498. Pp. 348-361.

[4] A. J. Barber, M.J. Crow, 2009. Structure of Sumatra and its implications for the tectonic assembly of Southeast Asia and the destruction of Paleotethys. Island Arc. Pp. 18, 3-20.

[5] A. J. Barber, M. J. Crow, dan J. S. Milsom, 2005. Sumatra: Geology, Resources, and Tectonic Evolution: London, Geological Society. 290 pp.

[6] Muraoka, H., Takahashi, T., Sundhoro, H., Dwipa, S., Soeda, Y., Momita, M., and Shimada, K. 2010. Geothermal systems constrained by the Sumatran fault and its pull-apart basin in Sumatra, Western Indonesia Proc. World Geothermal Congress. Pp. 28.

[7] Directorate General of New Energy, Renewable, and Energy Conservation. 2017. Indonesia Geothermal Potential on Geragai, Jambi Geothermal. Indonesia Ministry of Energy and Mineral Resource. Volume 2. Pp. 254-257.

[8] H. Darman, and F.H. Sidi, 2000. An Outline of The Geology of Indonesia. The Indonesian Association of Geologists. $192 \mathrm{pp}$.

[9] Indonesia Geospatial Agency (BIG) Digital Elevation Model National (DEMNAS) $8 \mathrm{~m}$. 